GEOGRAFICKÝ ČASOPIS / GEOGRAPHICAL JOURNAL 73 (2021) 1, 43-61

DOI: https://doi.org/10.31577/geogrcas.2021.73.1.03

\title{
VZDELANIE ŽIEN A ČASOVANIE RODENIA DETÍ NA SLOVENSKU V PRIESTOROVEJ PERSPEKTÍVE
}

\author{
Branislav Šprocha*, Vladimír Bačík** \\ * Centrum spoločenských a psychologických vied SAV, Šancová 56, 81105 Bratislava, \\ branislav.sprocha@gmail.com \\ ** Univerzita Komenského v Bratislave, Prírodovedecká fakulta, Katedra ekonomickej a sociálnej geografie, \\ demografie a územného rozvoja, Mlynská dolina, Ilkovičova 6, 84215 Bratislava, \\ vladimir.bacik@uniba.sk
}

\section{Female education and the timing of childbirth in Slovakia in a spatial perspective}

The fertility postponement transition represents one of the most important aspects of changes in the reproductive behaviour in Slovakia after 1989. An important aspect of these changes is the extension of the study period and the increase of women's education. The main goal of this article was to analyze possible spatial differences of selected aspects of fertility timing in connection with the achieved education of women. The effort was also to point out possible changes between the two periods - the beginning of the transformation process and the current state. The obtained results confirmed the considerable differentiation of the process of changes in the timing of fertility between individual educational groups. In the case of less educated women, we observe are witnessing a deepening age and spatial pluralization, the emergence of relatively significant spatial differences in the timing of fertility, while in the more educated persons we record are witnessing considerable age homogamy and fertility concentration.

Key words: fertility tempo, postponement transition, women's education, districts, Slovakia

\section{ÚVOD}

Jedným z hlavných znakov transformácie procesu plodnosti na Slovensku prebiehajúceho od začiatku 90. rokov 20. storočia je odkladanie rodenia detí do vyššieho veku (pozri napr. Potančoková et al. 2008 a Šprocha, ed. 2019). Ide pritom o historicky jedinečnú zmenu, pretože pre slovenské prostredie bola typická skôr snaha žien vstúpit' do manželstva a rodičovstva $v$ mladom až vel'mi mladom veku (napr. Šprocha a Tišliar 2018). Špecifické podmienky minulého politického režimu (bližšie napr. Sobotka 2002, 2004 a 2011) navyše výrazným spôsobom prispeli $\mathrm{k}$ upevneniu tohto reprodukčného modelu a odkladanie manželstva a materstva nebolo pre mladých žiaducou životnou stratégiou (Sobotka 2011). Až po roku 1989v kombinácii s celkovou spoločenskou, politickou, hospodárskou a kultúrnou premenou priniesli nástup dynamicky prebiehajúcej transformácie reprodukčného správania. Ako poukazujú niektorí autori (napr. Rychtaříková 2000, Frejka 2008 a Billingsley 2010), za dôležité faktory prepadu plodnosti a celkovej transformácie reprodukcie v krajinách bývalého východného bloku treba označit' viaceré štrukturálne determinanty. Predovšetkým prvé roky transformačného obdobia sa niesli v pôsobení takých negatívnych aspektov, akými boli prudká inflácia, rast neza- 
mestnanosti, odd'al'ovanie platieb, pokles reálnych príjmov, rozpad populačných politík, diskriminácia na trhu práce a pod., ktoré viedli k zhoršovaniu životnej úrovne a v niektorých skupinách obyvatel'stva k vzniku deprivácie a sociálnej anómie (pozri napr. Philipov 2003 a Frejka 2008). V d’alších fázach transformácie sa prejavili aj iné štrukturálne faktory, ktoré súviseli s presadzovaním trhového hospodárstva. Ide napríklad o reštrukturalizáciu trhu, rastúcu sút’až na trhu práce, potrebu flexibility, zvyšovania kvalifikácie a zručností, nové možnosti budovania kariéry, rast priamych a nepriamych výdavkov spojených so starostlivost'ou o deti a d'alšie (Frejka 2008).

Diskontinuita životných podmienok po roku 1989 znamenala pre väčšinu mladých mužov a žien postupne odmietanie skorých materstiev a nástup odkladania prvých pôrodov do vyššieho veku. S tým je úzko previazané aj časovanie rodenia d'alších detí, a preto sme svedkami celkového starnutia vekového profilu plodnosti (bližšie napr. Šprocha a Tišliar 2016). Nejde pritom len o zmeny v časovaní prvého materstva a rodičovstva, ale reštrukturalizáciou a významnými posunmi sú poznačené aj d'alšie dôležité prechody v životných dráhach mladých na ceste k dospelosti (Shanahan 2000 a Arnett 2004). Ako pre slovenské prostredie uvádza Potančoková (2013, p. 94), ,... sme svedkami fundamentálnej premeny životných dráh mladých dospelých, ktorá vyústila do zmeny a spôsobu načasovania formovania rodiny a ktorá súvisí s individualizačnými tendenciami." Stratégia skorého materstva a prerušenia pracovnej dráhy na jej začiatku bola vystriedaná, najmä u žien s vyšším vzdelaním, stratégiou akumulácie l'udského kapitálu a budovania profesijnej dráhy (Potančoková 2013).

Viaceré zahraničné štúdie (napr. Neels a De Wachter 2010, Mills et al. 2011, Ní Bhrolcháin a Beaujouan 2012 a Balbo et al. 2013), ku ktorým sa v posledných rokoch pridávajú aj niektoré domáce práce (napr. Šprocha a Potančoková 2010, Šprocha a Tišliar 2019), v spojitosti so zmenami v časovaní rodenia detí poukazujú na vel'ký význam predlžovania štúdia a celkovo zvyšovania dosiahnutého vzdelania. Práve vzdelanostná štruktúra patrí na Slovensku medzi najdynamickejšie sa meniace populačné štruktúry $\mathrm{s}$ jasným príklonom $\mathrm{k}$ vyšším stupňom vzdelania (bližšie napr. Bleha et al. 2014 a Sprocha a Tišliar 2019). Kým na začiatku 90. rokov malo vysokoškolské vzdelanie len necelých $9 \%$ žien v reprodukčnom veku $(15-49$ rokov), podl'a sčítania 2011 to už bolo takmer $23 \%$ a podl'a odhadu Štatistického úradu Slovenskej republiky (d'alej ŠÚ SR) z konca roka 2019 až približne jedna tretina. $\mathrm{V}$ rovnakom období pritom vo veku najvyššej plodnosti (25 - 34 rokov) podiel žien s vysokoškolským vzdelaním vzrástol z necelých $13 \%$ na takmer polovicu.

Možno preto očakávat', že spomínaná medzigeneračná vzdelanostná transformácia sa významným spôsobom podiel'ala na predlžovaní obdobia bezdetnosti, odkladaní rodenia druhých a d'alších detí a tým aj celkového vekového nastavenia procesu plodnosti na Slovensku. Prepojenie dľžky štúdia, či dosiahnutého vzdelania $\mathrm{s}$ časovaním rodenia detí je však analyzované takmer výlučne na národnej úrovni. Regionálna dimenzia a identifikácia prípadných regionálnych diferencií neboli na Slovensku doposial' predmetom žiadneho výskumu. Ciel'om predloženého príspevku je preto snaha nájst' odpoved' na otázku, či existujú na Slovensku rozdiely vo vybraných aspektoch časovania plodnosti $\mathrm{v}$ rámci jednotlivých vzdelanostných stupňov a tiež zistit', ako sa existujúce rozdiely medzi vzdelanostnými stupňami vyvíjali v čase a priestore. 


\section{VZDELANIE ŽIEN A PLODNOSŤ}

Vzdelanie žien predstavuje jeden z najdôležitejších diferenciačných znakov procesu plodnosti (pre Slovensko napr. Šprocha a Potančoková 2010, Šprocha a Tišliar 2019). Dlhodobo pritom na Slovensku môžeme identifikovat' negatívny vzdelanostný gradient, ked's rastúcim vzdelaním klesá realizovaná plodnost' (napr. Sprocha a Tišliar 2019). Zmeny po roku 1989 však prispeli k určitému vyrovnaniu rozdielov v úrovni plodnosti medzi najvzdelanejšími ženami a ženami so stredoškolským vzdelaním. Prispel k tomu hlavne významný pokles plodnosti u žien so stredoškolským vzdelaním bez maturity a najmä s maturitou. Príčinou bol predovšetkým pomerne významný prepad intenzity rodenia druhých a d’alších detí a čiastočne aj nárast rizika konečnej bezdetnosti. U žien s terciárnym vzdelaním, najmä vd’aka pomerne úspešnému dobiehaniu odložených pôrodov vo vyššom veku, sa intenzita plodnosti výraznejšie nezmenila. Výsledkom toho je situácia, ked’ najvyššiu plodnost' stále dosahujú ženy so základným vzdelaním, ale s už pomerne výrazným odstupom nasledujú osoby so stredoškolským vzdelaním bez maturity. Absolventky terciárneho stupňa už pritom majú vyššiu plodnost' ako ženy s úplným stredoškolským vzdelaním (bližšie pozri Šprocha a Tišliar 2019).

Rovnako transformačné obdobie na Slovensku prinieslo významné zmeny $\mathrm{v}$ časovaní rodenia detí medzi vzdelanostnými skupinami. S výnimkou najmenej vzdelaných žien sme svedkami odkladania rodenia detí do vyššieho veku. Aj $\mathrm{v}$ tomto prípade však tento proces najdynamickejšie prebiehal u žien so stredoškolským vzdelaním. Potvrdzujú to priamo aj údaje o časovaní rodenia prvých detí. Priemerný vek žien s vysokoškolským vzdelaním pri narodení prvého diet’ata sa zvýšil od začiatku 90. rokov 20. storočia z približne 29 na takmer 32 rokov, u žien so stredoškolským vzdelaním bez maturity došlo k nárastu z 24 nad 29 rokov a u žien s maturitou z 25 na 30 rokov.

Z regionálneho hladiska viaceré štúdie (napr. Jurčová a Mészáros, eds. 2010, Bleha et al. 2014 a Šprocha, ed. 2019) poukazujú na existenciu a dlhodobé pretrvávanie pomerne výrazných priestorových diferencií $\mathrm{v}$ intenzite i časovaní rodenia detí. V prípade intenzity rodenia detí sme najmä v poslednej dekáde svedkami určitej konvergencie, pričom ale došlo k značnému rozšíreniu priestoru s vel'mi nízkou až extrémne nízkou plodnostou, ktorá v podstate zasahuje s výnimkou Bratislavy a jej zázemia väčšinu okresov západného a stredného Slovenska. Súčasne do tejto skupiny môžeme zaradit’ aj okresy krajného východu, čím spolu s poklesom plodnosti na severe Slovenska došlo k zmenšeniu priestoru s nadpriemernou plodnost’ou (pozri napr. Šprocha, ed. 2019).

Z pohl'adu časovania rodenia detí môžeme vo všeobecnosti povedat', že všetky uvedené práce identifikovali postupne sa formujúcu výraznú diferenciáciu medzi severozápadom a juhovýchodom Slovenska. V podstate všetky okresy západného a väčšina celkov stredného Slovenska, $\mathrm{s}$ výnimkou juhoslovenského pásu, v súčasnosti predstavuje priestor s neskorším až neskorým vstupom žien do materstva. Na druhej strane vo väčšine okresov východného Slovenska a juhu stredného identifikujeme stále signifikantne skorší začiatok reprodukčných dráh. Výnimkou sú len niektoré okresy s dôležitými hospodárskymi centrami - okresy Košíc, Prešov a Humenné (bližšie pozri napr. Šprocha, ed. 2019).

Uvedené výsledky priestorových rozdielov však ani v jednom prípade nezohl'adňujú možné diferencie $\mathrm{v}$ dížke štúdia žien, či úrovne ich dosiahnutého vzdelania. Ako pritom ukazujú viaceré zahraničné práce (napr. Sobotka 2004, Mills et al. 
2011 a Ní Bhrolcháin a Beaujouan 2012), predlžovanie obdobia štúdia a nárast samotnej vzdelanostnej úrovne žien patria medzi najdôležitejšie faktory $\mathrm{v}$ procese transformácie plodnosti prejavujúce sa odkladaním rodenia detí. Vel'ký význam vzdelania pre časovanie rodenia detí má svoje opodstatnenie, ked' si uvedomíme, ako dosiahnuté vzdelanie ovplyvňuje rodinné a reprodukčné správanie (Hoem et al. 2006, Raymo et al. 2015, Osiewalska 2017 a Sobotka et al. 2017).

Prepojenie vzdelania žien a časovania reprodukcie môžeme vnímat' v dvoch rovinách. Priamy vplyv vychádza z poznania, že štúdium je t’ažko zlúčitel'né s úlohou matky a starostlivost'ou o deti (napr. Blossfeld a Huinink 1991, Kravdal 1994 a Baizán et al. 2003). Na Slovensku to potvrdzujú aj empirické údaje, ked' v posledných sčítaniach obyvatel'ov len minimálna čast' študentiek sa už stala matkami (pozri Šprocha a Tišliar 2016).

Okrem toho proces nadobúdania vyššieho vzdelania a predlžovania obdobia štúdia je tiež potrebné vnímat' aj v kontexte odkladania vstupu na trh práce, neskoršieho opustenia orientačnej rodiny, nadobudnutia rezidenčnej samostatnosti (Kohler et al. 2002 a Sobotka et al. 2017), čo sú vel'mi dôležité prechody pred začiatkom materskej dráhy.

Prevažná väčšina existujúcich analýz prepojenia dížky štúdia, dosiahnutého vzdelania žien a časovania rodenia detí (napr. Lappegård a Rønsen 2005, Neels a Wachter 2010, Ní Bhrolcháin a Beaujouan 2012 a Osiewalska 2017) tak poukazuje na skutočnost', že predlžovanie pôsobenia mladých osôb vo formálnom vzdelávaní a s tým súvisiaca zvyšujúca sa vzdelanostná úroveň majú za následok výrazné odkladanie „materských štartov“. To môže následne ovplyvňovat' aj načasovanie rodenia d'alších detí a tým celkový vekový priebeh procesu reprodukcie.

Druhým nepriamym aspektom je, že výsledná rozdielna vzdelanostná štruktúra je úzko prepojená s odlišným sociálnym a kultúrnym kapitálom osôb, ich postavením na trhu práce, výškou zárobku, ako aj diferencujúcimi sa hodnotovými orientáciami (Sobotka 2004). Tieto faktory vychádzajú priamo z teórie druhej demografickej revolúcie (bližšie van de Kaa 1987 a Lesthaeghe 2010). V kontexte jej hlavných dimenzií môžeme potom u najvzdelanejších osôb predpokladat' väčšś príklon k individualizmu, snahám o sebarealizáciu, osobnostný rozvoj, emancipáciu, širšie možnosti slobodnej vol'by, ktoré sa následne budú prejavovat' vo vekových normách a postojoch, kedy je príhodné stat' sa matkou (van de Kaa 1996 a Potančoková 2013). Ní Bhrolcháin a Beaujouan (2012) dopĺn̆ajú, že vzdelanejšie ženy vykazujú vyššiu ekonomickú participáciu na oficiálnom trhu práce, dosahujú vyššiu ekonomickú nezávislost', častejšie sa orientujú na budovanie svojej profesijnej kariéry a určitej pracovnej pozície. Tieto aspekty vytvárajú u nich vysoké náklady stratených príležitostí v prípade, že musia opustit' pracovný trh z dôvodu starostlivosti o deti a rodinu (Becker 1981). V prípade žien s nízkym vzdelaním, ktoré majú nestabilnú pozíciu na trhu práce a prípadne aj nízke príjmy, sú náklady stratených príležitostí starostlivost'ou o deti nízke, kým vzdelanejšie ženy opustením trhu práce strácajú ovel'a viac. Navyše nepriame náklady v podobe straty kontaktu so zamestnaním, dočasným zastavením profesijného rastu a pod. sú d’aleko vyššie ako priame finančné transfery (Becker 1960 a 1981). Negatívne pôsobenie materských a rodičovských povinností na kariérny rast môže so sebou prinášat prehodnocovanie reprodukčných stratégií a reprodukčných zámerov vo vzt’ahu k aktuálnej životnej situácii a d’alšiemu odkladaniu „materského štartu“, či narodeniu d'alšieho diet'at'a. 
V zmysle teórie redukcie neistoty (Friedman et al. 1994 a Hechter a Kanazawa 1997) môže byt' materstvo v mladom až vel'mi mladom veku nástrojom, ktorým sa najmä ženy s nízkym vzdelaním, nízkymi vzdelanostnými ašpiráciami, zo znevýhodneného prostredia a s problematickou pozíciou na trhu práce snažia redukovat' svoju životnú neistotu. Často pritom tieto reprodukčné vzory preberajú medzigeneračne alebo ich pozitívne vnímanie si osvojujú $\mathrm{v}$ rámci vrstovníckej skupiny. Okrem toho materstvo v mladom veku môže byt' tiež v ich prípade spájané so zaistením aspoň určitého príjmu a ako dôležitý faktor získania istej identity a statusu v miestnej spoločnosti (Sobotka et al. 2011).

\section{DÁTA A METÓDY}

Analýza časovania rodenia detí $\mathrm{v}$ dátových podmienkach Slovenska na regionálnej úrovni sa opiera o zist'ovanie Štatistického úradu Slovenskej republiky (d'alej ŠÚ SR) z rady Obyv 2-12 Hlásenie o narodení diet'at'a. V rámci neho sú každoročne vyčerpávajúco (teda za všetky narodené deti na území Slovenska) zbierané údaje týkajúce sa pôrodu - narodeného diet’at'a a jeho rodičov. V našej analýze sme spracovali informácie týkajúce sa roku pôrodu, vitality pôrodu (pracujeme len so živonarodenými det'mi), biologického poradia pôrodu, veku, najvyššieho vzdelania matky pri pôrode a miesta bydliska matky pri pôrode. $Z$ hl'adiska úrovne dosiahnutého vzdelania sú v Hlásení Obyv 2-12 aplikované štyri hlavné vzdelanostné skupiny (základné a bez vzdelania, stredoškolské bez maturity, stredoškolské s maturitu a vysokoškolské). Vzhl'adom na početnost' udalostí, najmä v niektorých menších okresoch Slovenska a v súlade s hlavnými trendmi v dosahovaní vzdelania medzi mladou generáciou žien, sme pristúpili k určitej redukcii uvedených kategórií. Ako nízke považujeme pre potreby našej práce vzdelanie základné, bez vzdelania a stredoškolské bez maturity. Stredoškolské vzdelanie s maturitou vytvára kategóriu stredného vzdelania a vysokoškolské sme označili ako vysoké vzdelanie.

Výhodou tohto typu zdroja údajov (napr. v porovnaní so sčítaním obyvatel'ov, domov a bytov) je, že umožňuje analyzovat' výšku dosiahnutého vzdelania žien priamo pri pôrode diet'at'a v kombinácii s jej vekom, miestom bydliska a rokom narodenia. Najnižšiu administratívnu jednotku, za ktorú sa zbierajú údaje, pritom predstavujú obce (resp. mestské časti v prípade Bratislavy a Košíc). Vzhl'adom na početnost štatistických udalostí je však pri regionálnej analýze zvolené triedenie do vyšších celkov. Aj napriek viacerým kritickým poznámkam k vyčleneniu okresov na Slovensku predstavujú tieto stále najčastejšie využívané a analyzované regionálne administratívne celky. Navyše sú od druhej polovice 90 . rokov 20. storočia stabilné, čo pri inom spôsobe vymedzenia regiónov (napr. funkčné mestské regióny) nemusí platit'. Obecná úroveň pri zbere údajov o narodených det'och nám pritom dovol'uje ,vyskladat“" rovnaké okresy pred aj po zmene administratívneho členenia v roku 1996, čo je dôležitým atribútom pre časový rámec našich ciel'ov. Ked’že anonymizované primárne dáta z Hlásení Obyv 2-12 sú dostupné od roku 1992 (vrátane) a vzhl'adom na populačnú vel'kost' niektorých menších okresov Slovenska sme zvolili dve pät'ročné obdobia. Prvé ohraničené rokmi 1992 a 1996 prezentuje začiatok transformačných zmien procesu plodnosti odkladaním. Umožňuje ešte do určitej miery poukázat' na charakter časovania plodnosti podl'a vzdelania žien v okresoch Slovenska pred tým, ako sa naplno presadil hlavný trend v reprodukčných dráhach mladých žien v podobe odkladania rodenia detí do vyššieho veku. Druhým obdobím sú roky 2015 - 2019, ktoré prezentujú posledný známy stav sledovanej problematiky 
Z hl'adiska použitých indikátorov boli pre obe zvolené obdobia, všetky tri vzdelanostné skupiny žien za každý okres Slovenska konštruované ukazovatele: priemerný vek ženy pri narodení diet’at'a, priemerný vek ženy pri narodení prvého diet'at'a, podiel plodnosti žien vo veku do 25 rokov, podiel plodnosti žien vo veku 30 a viac rokov a interkvartilové vekové rozpätie žien pri narodení diet'at'a. Prvé dva uvedené ukazovatele priamo umožňujú hodnotit' načasovanie plodnosti. Kým priemerný vek pri narodení diet'at'a indikuje rozloženie všetkých pôrodov, v prípade priemerného veku pri prvom diet'ati poukazujeme na nastavenie začiatku reprodukčných dráh. Proces odkladania rodenia detí do vyššieho veku sa vo všeobecnosti vyznačuje výrazným znížením plodnosti v mladšom veku (na Slovensku približne do 26. roku veku) a s nástupom procesu rekuperácie (dobiehania odložených reprodukčných zámerov) dochádza k zvyšovaniu plodnosti v staršom veku. To, ako sa tieto aspekty transformácie plodnosti odkladaním presadili medzi jednotlivými vzdelanostnými stupňami a v rámci jednotlivých okresov Slovenska, nám do určitej miery umožňuje sledovat' podiely plodnosti žien v mladom veku (do 25 rokov) a v druhej polovici reprodukčného obdobia (30 a viac rokov), ktoré sa stáva čoraz viac rozhodujúcim pre celkovú reprodukciu. Jedným z dôležitých znakov časovania plodnosti v období minulého politického režimu bola výrazná koncentrácia rodenia detí do úzkeho vekového intervalu. S ciel'om poukázat' na premenu tohto modelu a tiež identifikovat' prípadné diferencie medzi vzdelanostnými skupinami a okresmi Slovenska sa snažíme prostredníctvom nastavenia dolného a horného kvartilu veku pôrodnosti žien a z nich odvodeného interkvartilového rozpätia, ktoré nám umožňuje povedat', v akom širokom vekovom spektre sa realizuje polovica $\mathrm{z}$ celkovej reprodukcie.

\section{VZDELANIE ŽIEN A ČASOVANIE RODENIA DETÍ}

Výsledky z prvej polovice 90 . rokov 20. storočia potvrdzujú, že vo všetkých okresoch Slovenska platil pozitívny vzdelanostný gradient v časovaní rodenia prvých detí. Nie je tak prekvapením, že najdlhšie odkladali svoje „materské štarty“ vysokoškolsky vzdelané ženy $\mathrm{v}$ mestských okresoch Bratislavy a opačná situácia bola predovšetkým $\mathrm{v}$ páse juhovýchodných okresov (obr. 1). Ak sa zameriame na priestorové rozdiely v rámci jednotlivých vzdelanostných skupín, potom môžeme vidiet', že v tomto období ešte neboli medzi jednotlivými okresmi také výrazné diferencie v časovaní rodenia prvých detí, ako je tomu v súčasnosti. Týkalo sa to najmä žien s nízkym a stredným vzdelaním. V prípade osôb s terciárnym vzdelaním bolo možné už v tomto období identifikovat’ o niečo väčšiu vekovú pluralizáciu začiatku reprodukčných dráh. Možno preto povedat', že v prvej polovici 90 . rokov, s výnimkou najvzdelanejších žien, zatial' ešte neexistovali väčšie priestorové rozdiely v načasovaní prvých pôrodov (pozri obr. 1). Svedčí o tom napríklad aj hodnota variačného rozpätia priemerných vekov pri narodení prvého diet'at'a, ktorá sa u žien s nízkym vzdelaním pohybovala na úrovni dvoch rokov a u žien so stredným vzdelaním predstavovala niečo viac ako dva roky. V prípade osôb s vysokoškolským vzdelaním išlo však o viac ako štyri roky. Rovnako pozitívny vzdelanostný gradient nachádzame aj v prípade smerodajnej odchýlky (tab. 1).

Proces odkladania „materských štartov“ sa prejavil takmer vo všetkých vzdelanostných skupinách a okresoch Slovenska. Výnimku predstavovali ženy s nízkym vzdelaním vo viacerých okresoch na východe Slovenska, v ktorých došlo dokonca $\mathrm{k}$ miernemu poklesu hodnôt priemerného veku pri narodení prvého diet'at'a. Vd'aka tomu sa vytvoril pomerne zretel'ne identifikovatel'ný priestor okresov s pretrváva- 
júcou vel'mi nízkou hodnotou priemerného veku žien s nízkym vzdelaním pri narodení prvého diet'at'a (obr. 1). Na druhej strane, najmä v okresoch s vel'kými hospodárskymi centrami na západnom Slovensku (Bratislava, Trnava a Trenčín) došlo aj $\mathrm{v}$ tejto skupine žien $\mathrm{k}$ výraznému predíženiu obdobia bezdetnosti (o viac ako štyri roky). Obdobný trend, aj ked's nižšou dynamikou, môžeme identifikovat' i v d'alších okresoch predovšetkým západného a čiastočne stredného Slovenska, v dôsledku čoho sa vytvoril výrazný priestorový $\mathrm{V}-\mathrm{Z}$ gradient $\mathrm{v}$ časovaní začiatku reprodukčných dráh najmenej vzdelaných žien. Aj vd’aka tomu platí, že u žien s nízkym vzdelaním došlo k najvýraznejšej vekovej pluralizácii začiatku reprodukcie a teda vzniku najväčších priestorových rozdielov. Potvrdzuje to okrem iného aj hodnota variačného rozpätia, ktorá sa dostala signifikantne nad hranicu 7 rokov, ako aj smerodajná odchýlka, ktorá bola 4,5-krát vyššia ako v prvej polovici 90 . rokov 20. storočia.

A) Nízke vzdelanie $1992-1996$

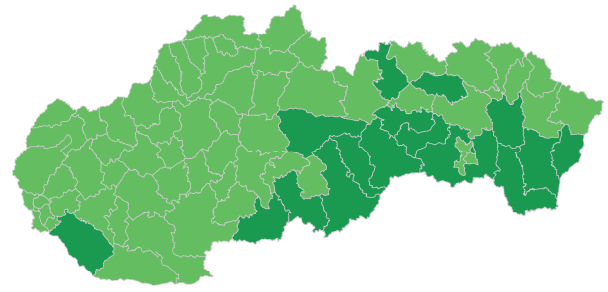

C) Stredné vzdelanie 1992 - 1996

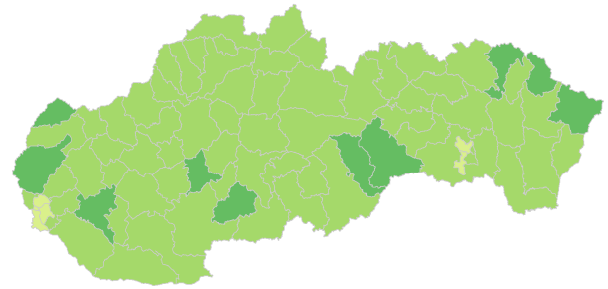

E) Vysoké vzdelanie 1992 - 1996

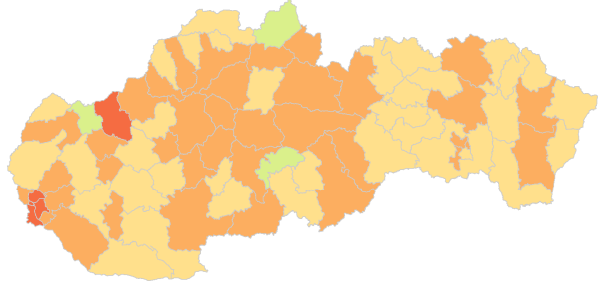

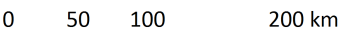

B) Nízke vzdelanie 2015 - 2019

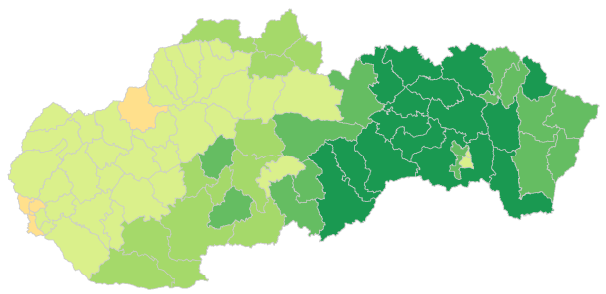

D) Stredné vzdelanie 2015 - 2019

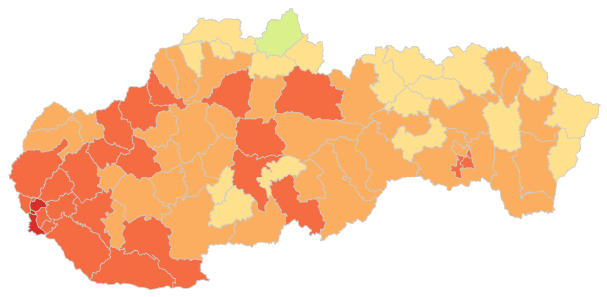

F) Vysoké vzdelanie 2015 - 2019

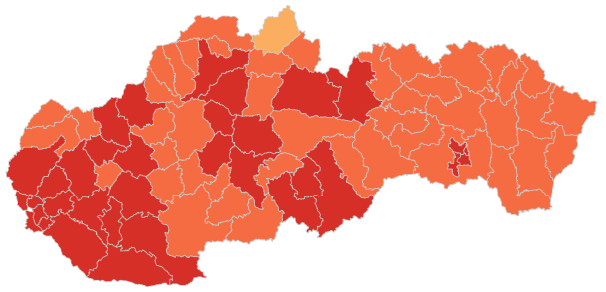

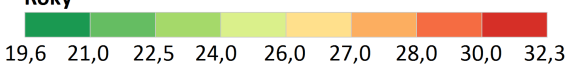

Obr. 1. Priemerný vek žien pri narodení prvého diet’at'a v okresoch Slovenska podl'a dosiahnutého vzdelania matiek v období rokov 1992 - 1996 a 2015 - 2019

Zdroj: ŠÚ SR (1992 - 1996 a 2015 - 2019 ), anonymizované primárne údaje Hlásenie Obyv 2-12, výpočty autorov. 
Tab. 1. Vybrané štatistické ukazovatele analyzovaných indikátorov časovania plodnosti žien podl'a najvyššieho dosiahnutého vzdelania $v$ okresoch Slovenska v období rokov 1992 - 1996 a 2015 - 2019

\begin{tabular}{|c|c|c|c|c|c|c|c|}
\hline \multirow{2}{*}{$\begin{array}{l}\text { Ukazovatel' } \\
\text { plodnosti }\end{array}$} & \multirow{2}{*}{ Štatistický ukazovatel' } & \multicolumn{3}{|c|}{$1992-1996$} & \multicolumn{3}{|c|}{$2015-2019$} \\
\hline & & Nízke & Stredné & Vysoké & Nízke & Stredné & Vysoké \\
\hline \multirow{4}{*}{$\begin{array}{l}\text { Priemerný vek } \\
\text { žien pri narodení } \\
\text { diet'ata }\end{array}$} & Minimum & 22,9 & 24,2 & 27,8 & 24,2 & 28,3 & 29,9 \\
\hline & Maximum & 26,3 & 27,5 & 31,5 & 29,3 & 32,3 & 33,4 \\
\hline & Variačné rozpätie & 3,5 & 3,3 & 3,7 & 5,1 & 4,0 & 3,5 \\
\hline & Smerodajná odchýlka & 0,6 & 0,6 & 0,6 & 1,5 & 0,7 & 0,6 \\
\hline \multirow{4}{*}{$\begin{array}{l}\text { Priemerný vek } \\
\text { žien pri narodení } \\
\text { 1. dietatata }\end{array}$} & Minimum & 20,3 & 22,1 & 25,7 & 19,6 & 25,0 & 27,9 \\
\hline & Maximum & 22,5 & 24,9 & 29,7 & 26,7 & 31,1 & 32,2 \\
\hline & Variačné rozpätie & 2,1 & 2,7 & 4,0 & 7,0 & 6,1 & 4,4 \\
\hline & Smerodajná odchýlka & 0,4 & 0,5 & 0,6 & 1,9 & 1,0 & 0,8 \\
\hline \multirow{4}{*}{$\begin{array}{l}\text { Podiel plodnosti } \\
\text { žien vo veku } \\
\text { do } 25 \text { rokov }\end{array}$} & Minimum & 48,6 & 41,3 & 7,0 & 28,4 & 9,3 & 0,9 \\
\hline & Maximum & 73,9 & 67,2 & 29,2 & 62,8 & 30,8 & 10,0 \\
\hline & Variačné rozpätie & 25,3 & 25,9 & 22,2 & 34,4 & 21,4 & 9,1 \\
\hline & Smerodajná odchýlka & 4,6 & 5,6 & 4,6 & 10,4 & 4,3 & 1,7 \\
\hline \multirow{4}{*}{$\begin{array}{l}\text { Podiel plodnosti } \\
\text { žien vo veku } 30 \\
\text { a viac rokov }\end{array}$} & Minimum & 8,8 & 8,4 & 24,3 & 18,9 & 34,5 & 43,1 \\
\hline & Maximum & 24,6 & 33,2 & 60,2 & 50,5 & 67,4 & 80,2 \\
\hline & Variačné rozpätie & 15,7 & 24,8 & 35,9 & 31,6 & 32,9 & 37,1 \\
\hline & Smerodajná odchýlka & 2,8 & 4,0 & 5,6 & 8,3 & 6,0 & 7,0 \\
\hline \multirow{4}{*}{$\begin{array}{l}\text { Interkvartilové } \\
\text { rozpätie plodnosti } \\
\text { žien }\end{array}$} & Minimum & 5,7 & 4,8 & 4,3 & 7,9 & 6,3 & 4,8 \\
\hline & Maximum & 8,6 & 9,2 & 8,4 & 13,0 & 8,9 & 6,1 \\
\hline & Variačné rozpätie & 2,8 & 4,3 & 4,1 & 5,1 & 2,6 & 1,3 \\
\hline & Smerodajná odchýlka & 0,6 & 0,6 & 0,7 & 1,0 & 0,4 & 0,3 \\
\hline
\end{tabular}

Zdroj: ŠÚ SR (1992 - 1996 a 2015 - 2019), anonymizované primárne údaje Hlásenie Obyv 2-12, výpočty autorov.

Jednoznačne najväčšími zmenami v časovaní rodenia prvých detí prešli ženy so stredným vzdelaním. Vo všetkých okresoch Slovenska bol nárast hodnôt ich priemerného veku pri narodení prvého diet'at'a najvyšší spomedzi všetkých analyzovaných vzdelanostných skupín. Platí to predovšetkým pre ženy s pobytom v okresoch Bratislavy a jej zázemia. Výrazne sa však predížilo obdobie bezdetnosti tejto vzdelanostnej skupiny aj na juhozápade, v páse okresov Považia, v niektorých okresoch stredného Slovenska s významnými hospodárskymi centrami (Martin, Banská Bystrica a Zvolen) a v mestských okresoch Košíc. Celkovo až v 31 okresoch prevažne západného a stredného Slovenska sa priemerný vek žien pri narodení prvého diet’at’a so stredným vzdelaním zvýšil o viac ako 5 rokov. Najmenšiu dynamiku proces odkladania rodenia prvých detí zaznamenal na severe stredného a východného Slovenska (obr. 1), čo sa následne odzrkadlilo aj na vzniku celkom výrazných priestorových rozdielov v časovaní prvého materstva tejto skupiny žien. O vekovej pluralizácii začiatku reprodukčných dráh svedčí aj variačné rozpätie priemerného veku pri narodení prvého diet'at'a, ktoré sa zväčšilo na viac ako 6 rokov, pričom smerodajná odchýlka sa takmer zdvojnásobila (tab. 1).

Celkovo najmenšiu pluralizáciu začiatku reprodukčných dráh nachádzame u žien s vysokým vzdelaním. Medzi sledovanými obdobiami došlo len k miernemu 
zväčšeniu variačného rozpätia (na 4,4 roku) a rovnako aj smerodajná odchýlka sa zvýšila len o približne pätinu (tab. 1). Prispel k tomu aj pomerne nízky (v porovnaní so ženami so stredným vzdelaním) rast hodnôt priemerného veku. V 40 okresoch sa u najvzdelanejších žien jeho hodnoty nezvýšili o viac ako tri roky a len v štyroch prípadoch to bolo o niečo viac ako štyri roky. S výnimkou okresu Námestovo sa vo všetkých stávajú ženy matkami prvýkrát po dovŕšení 28. roku života. Nad hranicou 30 rokov $\mathrm{k}$ tomu dochádza predovšetkým v priestore juhozápadného Slovenska, v niektorých okresoch stredného Slovenska a v mestských okresoch Košíc. Detailnejšie je možné priestorové rozdiely v časovaní začiatku reprodukčných dráh žien s vysokým vzdelaním pozorovat' na obr. 1.

Priemerný vek žien pri narodení diet'at'a (bez ohl'adu na poradie) úzko súvisí nielen s „materským štartom“, ale aj časovaním prípadných d’alších reprodukčných zámerov. Ked’že v prvej polovici 90 . rokov 20. storočia u žien s nízkym a stredným vzdelaním existovali medzi okresmi Slovenska len pomerne malé rozdiely v priemernom veku pri narodení prvého diet’at'a, dôležitým faktorom pre formovanie príslušných diferencií v hodnotách celkového priemerného veku (pozri obr. 2) sa stalo rodenie druhých a najmä d'alších detí. Ide predovšetkým o okresy severu stredného a východného Slovenska, ktoré sa vyznačovali vyššou úhrnnou i konečnou plodnost'ou, ako aj častejším zastúpením žien s tromi a viac det'mi (pozri Bleha et al. 2014). Vd'aka pomerne výraznej koncentrácii reprodukcie do relatívne úzkeho vekového intervalu (pozri obr. 3) sa v ostatných okresoch Slovenska hodnota priemerného veku pri narodení diet’at’a výraznejšie neodlišovala. V spojitosti so stredným a najmä vysokým vzdelaním môžeme tiež pri určitom zovšeobecnení povedat', že vyššie hodnoty priemerného veku žien pri narodení diet'at'a dosahovali tiež okresy s neskorším začiatkom reprodukcie (porovnaj obr. 1 a obr. 2). Na určitú vzájomnú blízkost' okresov z pohl'adu časovania reprodukcie v rámci jednotlivých vzdelanostných stupňov hovoria aj hodnoty variačného rozpätia $(3,5-3,7$ roka) a smerodajnej odchýlky $(0,56$ - 0,64 roka).

Odkladanie „materských štartov“ ovplyvňuje nielen začiatok reprodukčných dráh, ale významným spôsobom môže podmienit’ aj nastavenie časovania rodenia d'alších detí. To sa následne prejavuje v rôznom vývoji hodnôt priemerného veku žien pri narodení diet’at'a. Najväčší nárast sledovaného indikátora nachádzame u žien so stredným vzdelaním, u ktorých odkladanie rodenia prvých detí prebieha najintenzívnejšie. Celkom opačná situácia je pritom u žien s nízkym vzdelaním v niektorých okresoch východného Slovenska (obr. 2), ktoré vd’aka málo intenzívnemu odkladaniu, prípadne dokonca poklesu hodnôt priemerného veku žien pri narodení (prvého) diet'at'a zostávajú na vel'mi nízkych úrovniach (obr. 2). Na druhej strane v okresoch západného a väčšej časti stredného Slovenska dochádza aj $\mathrm{v}$ tejto vzdelanostnej skupine k starnutiu vekového profilu plodnosti, čoho výsledkom je pomerne dynamický rast priemerného veku žien pri narodení diet’at'a. Vytvára sa tak už spomínaný V-Z gradient v časovaní rodenia detí. Určitou výnimkou sú len okresy krajného východu, pri ktorých sa tiež presadil proces odkladania (obr. 2). Vd'aka značne rozdielnemu vývoju došlo v tejto vzdelanostnej skupine k vzniku najväčšej vekovej pluralizácie časovania reprodukcie, ked' sa variačné rozpätie pohybuje už nad hranicou 5 rokov a smerodajná odchýlka sa viac ako zdvojnásobila (1,5 roku) - pozri tab. 1 .

V prípade stredného vzdelania je priestorová situácia vel'mi podobná ako pri rodení prvých detí (porovnaj obr. 1 a 2). Nižšie hodnoty tak nachádzame v niektorých okresoch na severe a východe Slovenska. Naopak najvyšší priemerný 
vek pri pôrode dosahujú ženy v Bratislave a jej zázemí, v okrese Banská Bystrica, pričom nad hranicou 30 rokov sa nachádza d’alších 26 okresov (bližšie pozri obr. 2). Ako sme už uviedli, práve u žien so stredoškolským vzdelaním bolo možné na národnej úrovni identifikovat' prepad intenzity rodenia druhých a d'alších detí, a preto sa na celkovej plodnosti $\mathrm{v}$ prevažnej miere podiel'ajú $\mathrm{v}$ tejto vzdelanostnej skupine deti prvého poradia.

U žien s vysokým vzdelaním bola dynamika odkladania celkovej reprodukcie nižšia, no aj to postačuje na potvrdenie pozitívneho vzdelanostného gradientu vo všetkých okresoch Slovenska. Z priestorového hl'adiska tak môžeme identifikovat' len pomerne malé diferencie, ked' o niečo skôr sa $\mathrm{v}$ priemere rodia deti ženám s vysokoškolským vzdelaním len na severe stredného a vo viacerých okresoch východného Slovenska (obr. 2). Práve v tejto vzdelanostnej skupine došlo len k minimálnym zmenám v smerodajnej odchýlke v porovnaní s prvou polovicou 90 . rokov 20. storočia, pričom variačné rozpätie dokonca mierne kleslo.

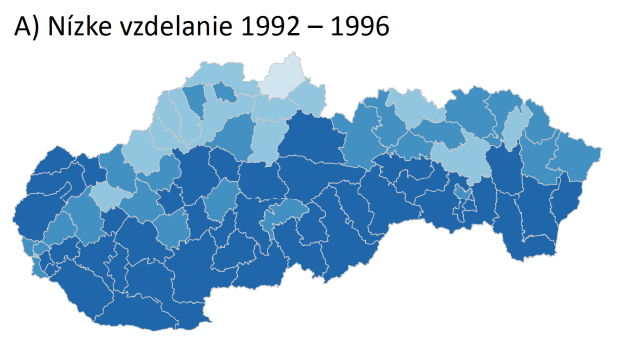

C) Stredné vzdelanie $1992-1996$

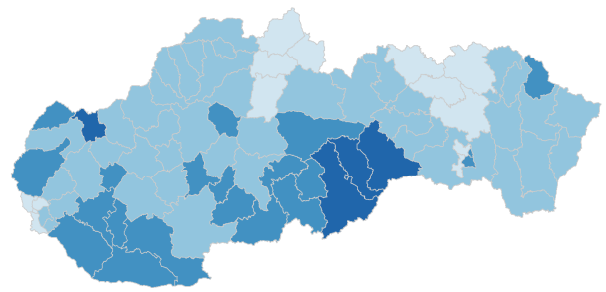

E) Vysoké vzdelanie $1992-1996$

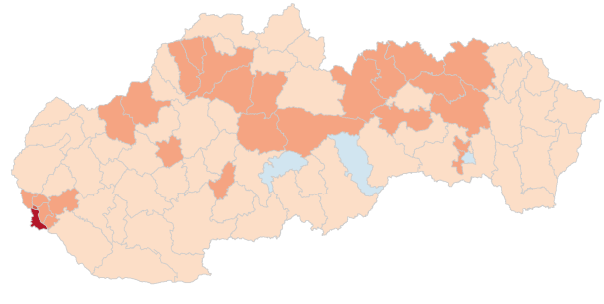

$0 \quad 50 \quad 100 \quad 200 \mathrm{~km}$
B) Nízke vzdelanie $2015-2019$

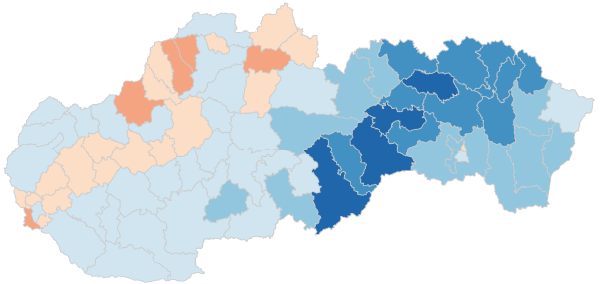

D) Stredné vzdelanie 2015 - 2019

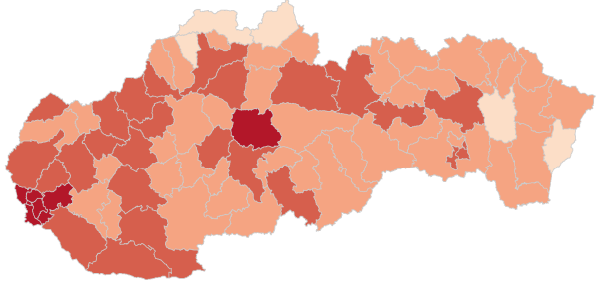

F) Vysoké vzdelanie 2015 - 2019

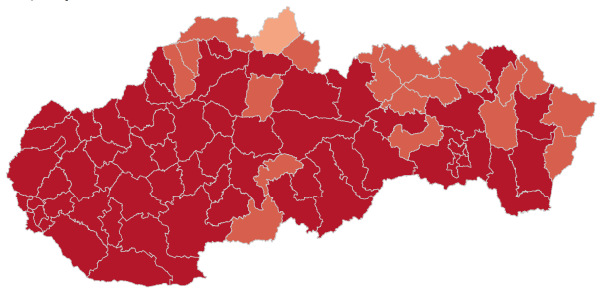
$22,8 \quad 24,5 \quad 25,0 \quad 26,0 \quad 28,0 \quad 29,0 \quad 30,0 \quad 31,0 \quad 33,5$

Obr. 2. Priemerný vek žien pri narodení diet’at’a v okresoch Slovenska podla dosiahnutého vzdelania matiek v období rokov 1992 - 1996 a 2015 - 2019

Zdroj: ŠÚ SR (1992 - 1996, 2015 - 2019), anonymizované primárne údaje Hlásenie Obyv 2-12, výpočty autorov. 


\section{PRÍSPEVKY VYBRANÝCH VEKOVÝCH SKUPÍN K CELKOVEJ PLODNOSTI A VZDELANIE ŽIEN}

Priemerný vek žien pri narodení (prvého) diet'at'a prezentuje len jednu čast' vekového nastavenia rozloženia plodnosti. Ďalší aspekt časovania plodnosti umožňujú sledovat' príspevky (podiely) určitých vekových skupín k jej celkovej úrovni. Pre naše účely sme vybrali vek do 25 rokov a vek 30 a viac rokov. Kým prvý interval bol v minulom reprodukčnom režime základom, v súčasnosti je rodenie detí v tomto veku výrazne na ústupe a často je vnímané skôr negatívne (Potančoková 2013). Symptomatickým javom nového modelu reprodukčného správania sa tak stáva odkladanie reprodukčných zámerov až do druhej polovice reprodukčného obdobia ženy (Lesthaeghe a Moors 2000), ktoré prezentuje práve druhý nami zvolený interval.

Skorý začiatok materstva u žien s nízkym vzdelaním a vysoké pravdepodobnosti, že sa stanú v mladom veku matkami aj d’alších detí (pozri Sprocha a Tišliar 2019), spôsobili skutočnost', že v tejto vzdelanostnej skupine v podstate takmer všetky okresy (výnimkou bol okres Námestovo) mali v prvom sledovanom období prevahu plodnosti žien vo veku do 25 rokov. Zaujímavost'ou je tiež existencia určitých priestorov najmä na severe Slovenska, ktorá sa vyznačovala mierne nižšou váhou (vzhl'adom na danú vzdelanostnú skupinu). Opätovne to môžeme vo väčšine prípadov pripisovat' častejšiemu rodeniu detí vyšších poradí vo veku nad 25 rokov.

Nadpolovičné zastúpenie táto veková kategória mala v prvej polovici 90 . rokov 20. storočia aj u žien so stredným vzdelaním. Výnimkou boli len okresy Bratislavy, okres Banská Bystrica, dva mestské okresy Košíc a niektoré celky na severe a východe Slovenska (obr. 3). V tomto prípade už nižšia váha bola v najväčších centrách výsledkom častejšieho posunu začiatku reprodukcie do vyššieho veku (pozri obr. 1) a v posledných dvoch menovaných priestoroch to mohol byt' tiež efekt častejšieho príklonu $\mathrm{k}$ početnejšej rodine.

Jednoznačne identifikovaný neskorší začiatok reprodukcie u žien s vysokým vzdelaním v prvej polovici 90. rokov je hlavným faktorom celkovo nízkeho vplyvu plodnosti vo veku do 25 rokov na jej celkovú intenzitu. Na druhej strane je však potrebné tiež doplnit', že len v dvoch okresoch Bratislavy predstavoval tento príspevok menej ako desatinu a súčasne v 19 okresoch sa pohyboval v rozpätí 20 $30 \%$. Nedá sa tak povedat', že by plodnost' v spomínanom veku zohrávala v tomto období pre celkovú reprodukciu žien s vysokým vzdelaním úplne zanedbatel'nú úlohu. Dané tvrdenie sa tak dá aplikovat' až na súčasný stav, ked’ až v 65 okresoch sú príspevky plodnosti vo veku do 25 rokov nižšie ako $5 \%$ a len v okrese Námestovo atakujú hranicu $10 \%$.

$\mathrm{K}$ výraznej redukcii váhy plodnosti žien $\mathrm{v}$ mladom veku došlo aj u žien so stredným vzdelaním. Opätovne môžeme vidiet' (obr. 3), že v súčasnosti dominujú okresy, kde sa váha plodnosti v tomto veku pohybuje v rozmedzí 15 - 30\%, kým $\mathrm{v}$ prvom sledovanom období takúto úroveň nedosahoval ani jeden okres. O niečo vyšší podiel dosahovali len ženy v Námestove a naopak do úrovne 15 \% sú príspevky v okrese Banská Bystrica, Košice III, Senec a v mestských okresoch Bratislavy (s výnimkou Bratislavy II).

U najmenej vzdelaných žien vývoj priniesol spomínané vyprofilovanie V-Z gradientu, ked' v západných a väčšine stredoslovenských okresoch je podiel plodnosti už pod hranicou $50 \%$. Nadpolovičné zastúpenie zostáva nad'alej vo väčšine regiónoch východného Slovenska (pozri obr. 3). 


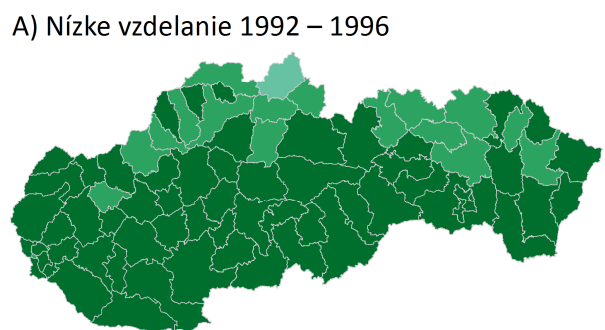

C) Stredné vzdelanie $1992-1996$

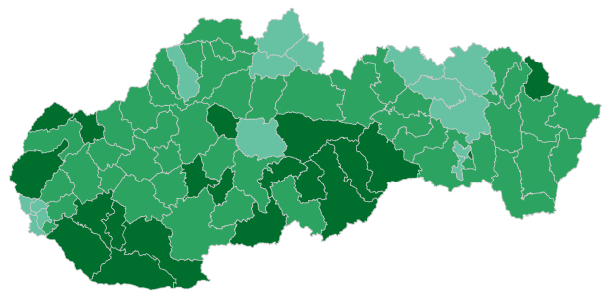

E) Vysoké vzdelanie $1992-1996$

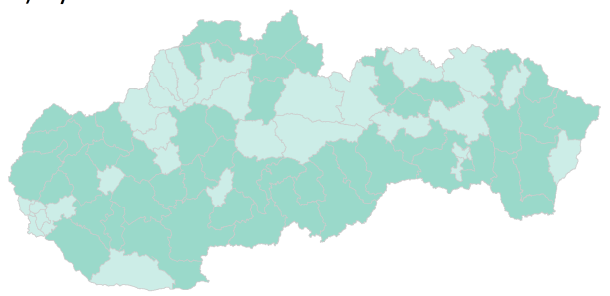

B) Nízke vzdelanie 2015 - 2019

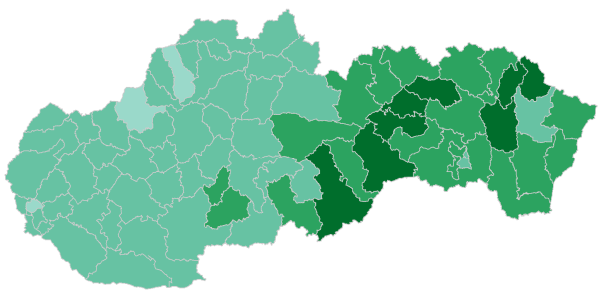

D) Stredné vzdelanie 2015 - 2019

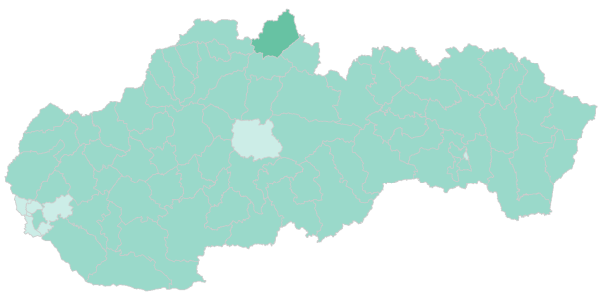

F) Vysoké vzdelanie 2015 - 2019

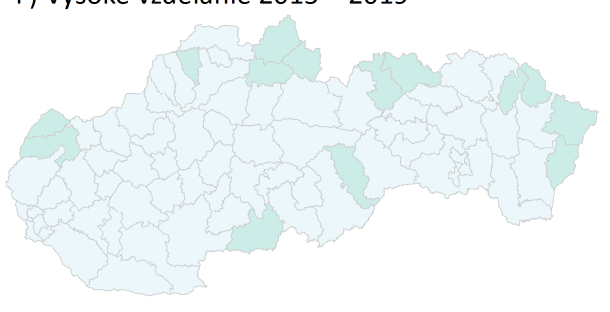

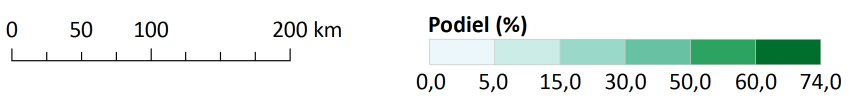

Obr. 3. Podiel plodnosti žien vo veku do 25 rokov podl'a dosiahnutého vzdelania matiek v okresoch Slovenska v období rokov 1992 - 1996 a 2015 - 2019

Zdroj: ŠÚ SR (1992 - 1996 a 2015 - 2019), anonymizované primárne údaje Hlásenie Obyv 2-12, výpočty autorov.

Vzhl'adom na výraznú koncentráciu plodnosti a skoré ukončovanie reprodukčných dráh žien často ešte pred dovíšením 30. roku života v období minulého politického režimu (pozri napr. Šprocha a Tišliar 2016), druhá polovica reprodukčného obdobia bola pre väčšinu okresov u žien so stredným a nízkym vzdelaním využívaná len v značne obmedzenej miere (do $15 \%$, resp. $20 \%$ - obr. 4). Určitou výnimkou boli len spomínané severné okresy Slovenska. Súčasne tiež predsa len platilo, že so zvyšujúcim sa vzdelaním žien zohrávala táto veková kategória väčšiu úlohu vo viacerých okresoch. Prevahu mala plodnost' v druhej polovici reprodukčného veku len v okrese Bratislava V. V súčasnosti je tento stav možné identifikovat' v takmer všetkých okresoch Slovenska (obr. 4). Jednoznačne najvyššie príspevky pritom dosahujú mestské okresy Bratislavy, okres Senec, Banská Bystrica a dva okresy Košíc (III a IV) s viac ako 70 \%. 
Najdynamickejšie prebiehajúci proces odkladania u žien so stredným vzdelaním znamenal, že v žiadnom okrese Slovenska už podiel plodnosti vo veku 30 a viac rokov nie je nižší ako $30 \%$, pričom len v 5 neprekračuje úroveň $40 \%$. Prevahu tak majú celky so 40 - $50 \%$ podielom, pričom nadpolovičné zastúpenie identifikujeme predovšetkým s najviac posunutým začiatkom reprodukčných dráh (obr. 1 a 4).

Vývoj v skupine žien s nízkym vzdelaním kopíruje predchádzajúce zistenia o V-Z gradiente. V okresoch západného a väčšej časti stredného Slovenska došlo k pomerne výraznému nárastu váhy plodnosti žien vo veku 30 a viac rokov, kým vo viacerých celkoch východného Slovenska (obr. 4) identifikujeme menej dynamický rast. Súčasne je však potrebné povedat', že k zvýšeniu príspevkov došlo s výnimkou okresu Stará L’ubovňa vo všetkých celkoch.

A) Nízke vzdelanie $1992-1996$

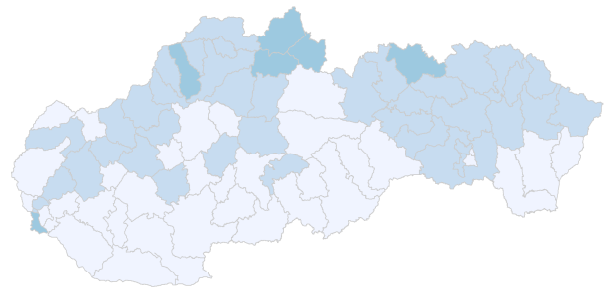

C) Stredné vzdelanie $1992-1996$

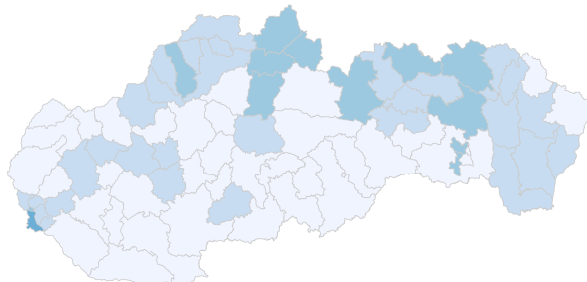

E) Vysoké vzdelanie $1992-1996$

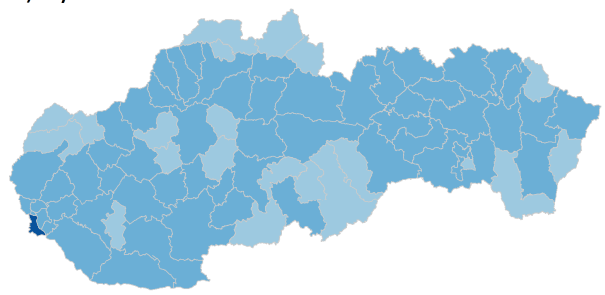

$0 \quad 50 \quad 100 \quad 200 \mathrm{~km}$

Podiel (\%)
B) Nízke vzdelanie $2015-2019$

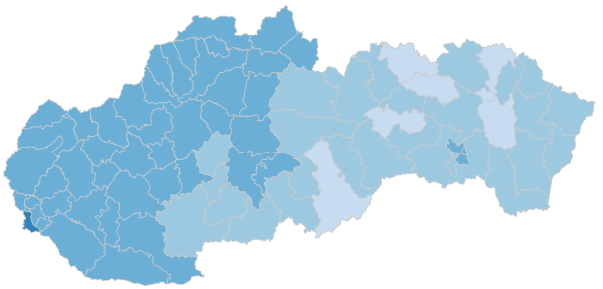

D) Stredné vzdelanie 2015 - 2019

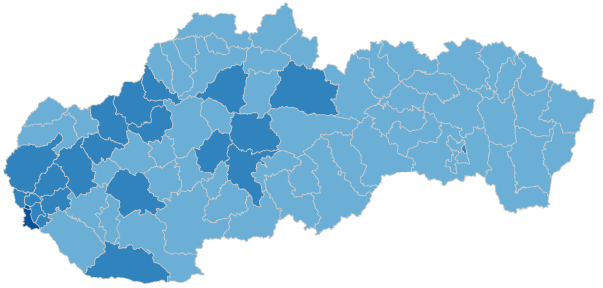

F) Vysoké vzdelanie 2015 - 2019

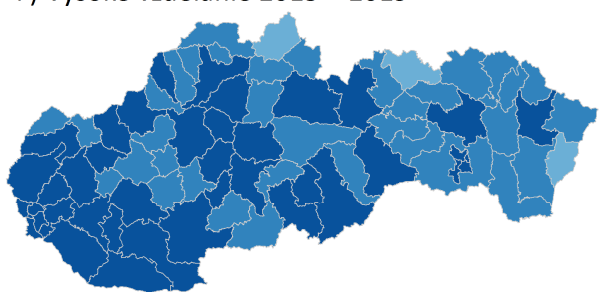

$8,0 \quad 15,0 \quad 20,0 \quad 30,0 \quad 50,0 \quad 60,0 \quad 81,0$

Obr. 4. Podiel plodnosti žien vo veku 30 a viac rokov podl'a dosiahnutého vzdelania matiek v okresoch Slovenska v období rokov 1992 - 1996 a 2015 - 2019

Zdroj: ŠÚ SR (1992 - 1996 a 2015 - 2019), anonymizované primárne údaje Hlásenie Obyv 2-12, výpočty autorov. 


\section{KONCENTRÁCIA REPRODUKCIE A VZDELANIE ŽIEN}

Skorý začiatok rodenia prvých detí, prehlbujúca sa orientácia predovšetkým na dvojdetný model rodiny v kombinácii s niektorými opatreniami populačnej politiky vytvárali predpoklady pre vznik špecifického modelu plodnosti koncentrované do pomerne úzkeho vekového intervalu (Potančoková et al. 2008 a Šprocha a Tišliar 2016). Pri pohl'ade na obr. 5 je zrejmé, že najnižšie hodnoty dosahovalo interkvartilové rozpätie na začiatku 90. rokov u najvzdelanejších osôb, u ktorých vo väčšine okresov sa polovica plodnosti realizovala v 6 rokoch. S klesajúcim stupňom dosiahnutého vzdelania sa táto koncentrácia zmenšovala, pričom u žien so stredným a najmä nízkym vzdelaním bola plodnost' rozprestretá do širšieho vekového intervalu (v tomto období) predovšetkým v okresoch severného a východného Slovenska (obr. 5). Platí, že ak ženy začínali so svojou reprodukciou skôr a výsledkom ich reprodukčnej histórie bolo častejšie $\mathrm{v}$ priemere viac detí (tri a viac), potom aj v týchto okresoch interkvartilové rozpätie dosahovalo najvyššie hodnoty.

A) Nízke vzdelanie $1992-1996$

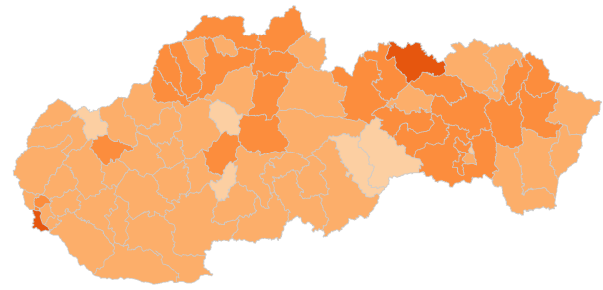

C) Stredné vzdelanie $1992-1996$

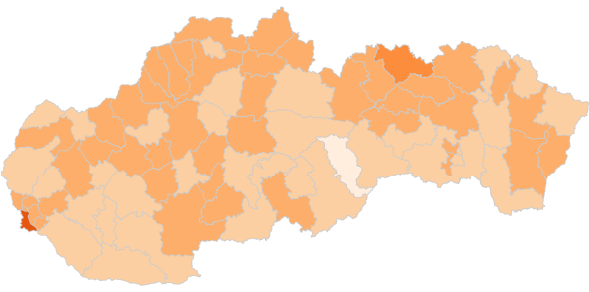

E) Vysoké vzdelanie $1992-1996$

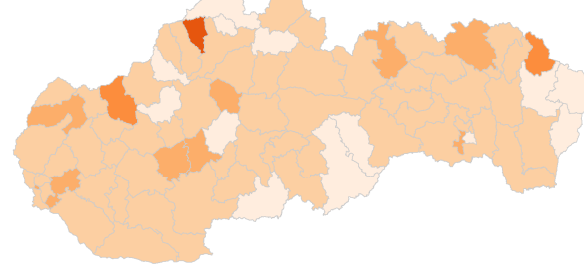

B) Nízke vzdelanie 2015 - 2019

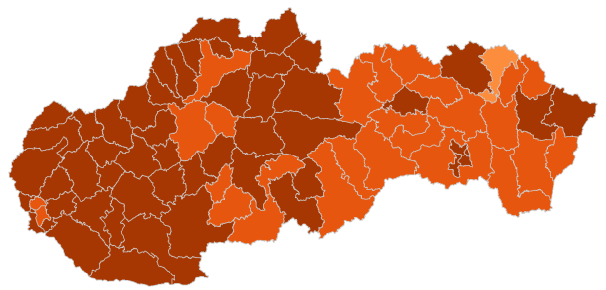

D) Stredné vzdelanie 2015 - 2019

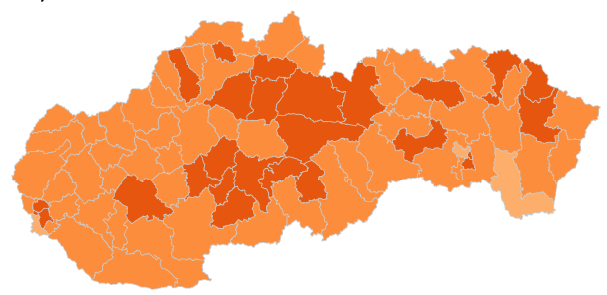

F) Vysoké vzdelanie 2015 - 2019

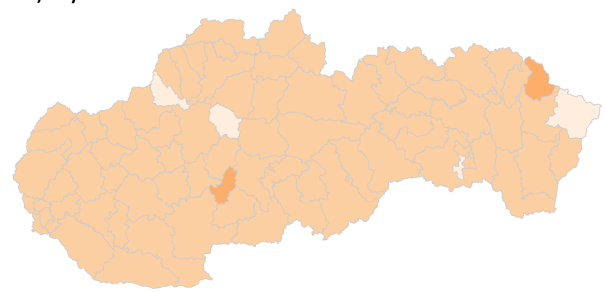

$0 \quad 50 \quad 100 \quad 200 \mathrm{~km}$

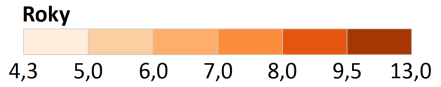

Obr. 5. Interkvartilové rozpätie plodnosti žien podl'a dosiahnutého vzdelania matiek v okresoch Slovenska v období rokov 1992 - 1996 a 2015 - 2019

Zdroj: ŠÚ SR (1992 - 1996 a 2015 - 2019 ), anonymizované primárne údaje Hlásenie Obyv 2-12, výpočty autorov. 
Zmeny v časovaní reprodukcie prebiehajúce $\mathrm{v}$ podstate vo všetkých okresoch Slovenska a viac-menej aj vo všetkých vzdelanostných stupňoch prispeli k výraznej premene modelu prevažujúcej koncentrácie plodnosti. Netýka sa to však najvzdelanejších žien, u ktorých došlo $\mathrm{v}$ podstate takmer k rovnakému posunu dolného i horného kvartilu a tým k zotrvaniu realizácie polovice reprodukčných plánov v krátkom intervale v priebehu 5 - 6 rokov (obr. 5) bez významnejších priestorových rozdielov. V prípade žien so stredným vzdelaním bol vo všeobecnosti rast hodnôt horného kvartilu plodnosti rýchlejší, čo znamenalo takmer vo všetkých okresoch rozšírenie vekového intervalu, v ktorom sa koncentruje polovica reprodukcie. Najvyššiu vekovú pluralizáciu v tejto vzdelanostnej skupine pritom identifikujeme na strednom a v niektorých okresoch východného Slovenska (obr. 5). Jednoznačne najväčšími zmenami prešla najmenej vzdelaná skupina žien. Ako sme ukázali, vo viacerých okresoch východného Slovenska začiatok reprodukcie neprešiel takmer žiadnymi posunmi a naopak na západe dolný kvartil pomerne významne vzrástol. Súčasne však v tomto priestore ešte rýchlejšie dochádzalo $\mathrm{k}$ posunu horného kvartilu a výsledkom je tak najvýraznejšia veková pluralizácia spomedzi všetkých vzdelanostných skupín. Ako je zrejmé z obr. 5, týka sa to predovšetkým celkov západného a v prevažnej miere aj stredného Slovenska, kým na východe je plodnost' týchto žien predsa len o niečo vekovo koncentrovanejšia.

\section{ZÁVERY}

Získané výsledky potvrdili zistenia viacerých doterajších štúdií analyzujúcich časovanie plodnosti na regionálnej úrovni na Slovensku (napr. Bleha et al. 2014 a Šprocha, ed. 2019). Ide predovšetkým o to, že v transformačnom období identifikujeme nástup procesu odkladania rodenia detí do vyššieho veku vo všetkých okresoch. Naše informácie poukazujú na to, že k tomu došlo takmer vo všetkých sledovaných vzdelanostných skupinách. Výnimkou sú niektoré okresy na východe Slovenska $\mathrm{v}$ prípade žien $\mathrm{s}$ nízkym vzdelaním, kde môžeme vidiet' stagnáciu až mierny posun začiatku reprodukčných dráh žien do nižšieho veku, čo ovplyvnilo aj d'alšie sledované indikátory časovania rodenia detí. Na druhej strane u týchto najmenej vzdelaných žien však na západe republiky možno pozorovat' pomerne dynamické odkladanie, čím došlo k výraznej vekovej pluralizácii začiatku reprodukcie a teda k vzniku najväčších priestorových rozdielov s jasným V-Z gradientom. Môžeme predpokladat', že kým na východe Slovenska sú zistené tendencie do značnej miery podmienené najmä osobami žijúcimi v priestore marginalizovaných rómskych komunít, u ktorých skorší začiatok reprodukcie môže byt' cestou ako riešit' svoju krízovú situáciu (v zmysle Hechter a Kanazawa 1997), na západe sú predsa len aj u žien s nízkym vzdelaním možnosti uplatnenia na trhu práce lepšie a teda náklady stratených príležitostí pri skorom až vel'mi skorom materstve väčšie. Navyše v prípade tejto skupiny sa dá v prostredí pomerne silnej vzdelanostnej párovej homogamie (Šprocha a Džambazovič 2020) predpokladat' horšie postavenie pri hl'adaní stabilného partnera, čo tiež negatívne ovplyvňuje ich rozhodovacie procesy pre začiatok reprodukčných dráh.

Významnými zmenami tiež prešlo aj časovanie plodnosti žien so stredným vzdelaním. V kontexte zistení Šprochu a Tišliara (2019) sa tak aj na okresnej úrovni potvrdzujú pomerne dynamicky prebehajúce tendencie odkladania reprodukčných zámerov u žien so strednou školou bez maturity a najmä s maturitou. $\mathrm{Aj}$ v tomto prípade je zrejmé vytvorenie pomerne súvislého priestoru na západe republiky s dlhším odkladaním „materských štartov“ a posunom vekového profilu do 
priemerne vyššieho veku, kým naopak na severe a severovýchode Slovenska identifikujeme skoršie rodenie detí.

Pri porovnaní s ostatnými dvomi vzdelanostnými skupinami možno povedat', že celkovo najmenšími zmenami v časovaní plodnosti prešla nielen na národnej, ale aj na regionálnej úrovni plodnost' žien s vysokým vzdelaním. Na druhej strane však aj u týchto žien identifikujeme viaceré dôležité transformačné premeny. Jednak došlo k posunu „materských štartov“, celého vekového profilu plodnosti, výraznej redukcii plodnosti žien v mladom veku a naopak zvýraznenie plodnosti v druhej polovici reprodukčného obdobia. Súčasne ide o vzdelanostnú skupinu, pri ktorej identifikujeme najnižšiu priestorovú vekovú pluralizáciu začiatku plodnosti, ako aj celkovej reprodukcie. Aj napriek tomu však môžeme pri určitom zovšeobecnení povedat', že existujú určité rozdiely najmä medzi viacerými okresmi západného a v podstate celým východným Slovenskom (okrem mestských okresov Košíc). Ukazuje sa, že aj pri zohl'adnení vplyvu najvyššieho dosiahnutého vzdelania ako významného diferenciačného faktora môžeme medzi okresmi Slovenska identifikovat' existenciu nezanedbatel'ných rozdielov v jednotlivých charakteristikách časovania plodnosti. Je zrejmé, že ich vysvetlenie bude podmienené niektorými d'alšími determinantmi ekonomickej (napr. nezamestnanost', priemerná mzda a kvalita bývania), kultúrnej (národnost' a náboženstvo) či geograficko-demografickej povahy (miera urbanizácie, poloha regiónu, dopravná obslužnost', rodinný stav žien v reprodukčnom veku, charakter rodín a domácností a pod.). Práve ich zohl'adnenie by malo byt' ciel'om hlbšieho a komplexnejšieho výskumu procesu odkladania rodenia detí a celkovej premeny časovania procesu plodnosti na Slovensku v regionálnom kontexte.

Štúdia je čiastkovým výsledkom projektu VEGA 2/0064/20 Pokračujúca transformácia rodinného a reprodukčného správania na Slovensku v časovom a priestorovom aspekte a APVV-17-0079 Analýza a prognóza demografického vývoja Slovenskej republiky $v$ horizonte 2080: identifikácia a modelovanie dopadov na sociálno-ekonomickú sféru v rozličných priestorových mierkach.

\section{LITERATÚRA}

ARNETT, J. (2004). Emerging adulthood. The winding road from late teens through the twenties. Oxford (Oxford University Press).

BAIZÁN, P., AASSVE, A., BILLARI, C. F. (2003). Cohabitation, marriage, and first birth: The interrelationship of family formation events in Spain. European Journal of Population 19, 147-169. DOI: https://doi.org/10.1023/A:1023343001627.

BALBO, N., BILLARI, F. C., MILLS, M. C. (2013). Fertility in advanced societies: A review of research. European Journal of Population, 29, 1-38. DOI: https:// doi.org/10.1007/s10680-012-9277-y.

BECKER, G. S. (1960). An economic analysis of fertility. In NBER, ed. Demographic and economic change in developed countries. Princeton (National Bureau of Economic Research), pp. 209-240.

BECKER, G. S. (1981). A treatise on the family. Cambridge (Harvard University Press).

BILLINGSLEY, S. (2010). The post-communist fertility puzzle. Population Research Policy Review, 29, 193-231. DOI: https://doi.org/10.1007/s11113-009-9136-7.

BLOSSFELD, H.-P., HUININK, J. (1991). Human capital investments or norms of role transition? How women's schooling and career affect the process of family formation. American Journal of Sociology, 97, 143-168. DOI: https://doi.org/10.1086/229743.

BLEHA, B., VAŇO, B., BAČIK, V. (2014). Demografický atlas Slovenskej republiky. Bratislava (Geografika). 
FREJKA, T. (2008). Determinants of family formation and childbearing during the societal transition in Central and Eastern Europe. Demographic Research, 19, 139-177. DOI: https://doi.org/10.4054/DemRes.2008.19.7.

FRIEDMAN, D., HECHTER, M., KANAZAWA, S. (1994). Theory of the value of children. Demography, 31, 375-401. DOI: https://doi.org/10.2307/2061749.

HECHTER, M., KANZAWA, S. (1997). Sociological rational choice theory. Annual Review Sociology, 23, 191-214. DOI: https://doi.org/10.1146/annurev.soc.23.1.191.

HOEM, J. M., NEYER, G., ANDERSSON, G. (2006). Education and childlessness. The relationship between educational field, educational level, and childlessness among Swedish women born in 1955 - 59. Demographic Research, 14, 331-380. DOI: https:// doi.org/10.4054/DemRes.2006.14.15.

JURČOVÁ, D., MÉSZÁROS, J., eds., PILINSKÁ, V., POTANČOKOVÁ, M., ŠPROCHA, B. (2010). Populačný vývoj v okresoch Slovenskej republiky v roku 2009. Bratislava (INFOSTAT).

KOHLER, H. P., BIALLRI, F. C., ORTEGA, J. A. (2002). The emergence of lowest-low fertility in Europe during the 1990s. Population and Development Review, 28, 641-680. DOI: https://doi.org/10.1111/j.1728-4457.2002.00641.x.

KRAVDAL, Ø. (1994). The importance of economic activity, economic potential and economic resources for the timing of first births in Norway. Population Studies, 48, 249267. DOI: https://doi.org/10.1080/0032472031000147786.

LAPPEGÅRD, T., RØNSEN, M. (2005). The multifaceted impact of education on entry into motherhood. European Journal of Population, 21, 31-49. DOI: https:// doi.org/10.1007/s10680-004-6756-9.

LESTHAEGHE, R. (2010). The unfolding story of the second demographic transition. Population and Development Review, 36, 211-251. DOI: https://doi.org/10.1111/j.17284457.2010.00328.x.

LESTHAEGHE, R., MOORS, G. (2000). Recent trends in fertility and household formation in the industrialized world. Review of Population and Social Policy, 9, 121-170.

MILLS, M. C., RINDFUSS, R. R., MCDONALD, P., TE VELDE, E. (2011). Why do people postpone parenthood? Reasons and social policy incentives. Human Reproduction Update, 17, 848-860. DOI: https://doi.org/10.1093/humupd/dmr026.

NÍ BHROLCHÁIN, M., BEAUJOUAN, É. (2012). Fertility postponement is largely due to rising educational enrolment. Population Studies, 66, 311-327. DOI: https:// doi.org/10.1080/00324728.2012.697569.

NEELS, K., DE WACHTER, D (2010). Postponement and recuperation of Belgian fertility: How are they related to rising female educational attainment? Vienna Yearbook of Population Research, 8, 77-106.

OSIEWALSKA, B. (2017). Childlessness and fertility by couples'educational (in)equality in Austria, Bulgaria and France. Demographic Research, 37, 325-362. DOI: https:// doi.org/10.4054/DemRes.2017.37.12.

PHILIPOV, D. (2013). Fertility in times of discontinuous societal changes. In Kotowska, I., Józwiak, J., eds. Population of Central and Eastern Europe, challenges and opportinuties. Warsaw (Statistical Publishing Establishment), pp. 665-689.

POTANČOKOVÁ, M. (2013). Rodina a životné dráhy mladých dospelých. In Krivý, V., ed. A ko sa meni slovenská spoločnost'. Bratislava (IRIS), pp. 89-127.

POTANČOKOVÁ, M., VAŇO, B., PILINSKÁ, V., JURČOVÁ, D. (2008). Slovakia: Fertility between tradition and modernity. Demographic Research, 7, 973-1015. DOI: https://doi.org/10.4054/DemRes.2008.19.25.

RAYMO, J. S., Van ORMAN, A., PERELLI-HARRIS, B., CARLSON, M., LIM, S., IWASAWA, M. (2015). Educational differences in early childbearing: A cross-national comparative study. Demographic Research, 33, 65-92. DOI: https://doi.org/10.4054/ DemRes, 2015.33.3.

RYCHTAŔIKOVÁ, J. (2000). Demographic transition or demographic shock in recent population development in the Czech Republic. Acta Universitatis Carolinae, Geographica, 1, 89-102. 
SHANAHAN, M.J. (2000). Pathways to adulthood in changing societies: Variability and mechanisms in life course perspective. Annual Review of Sociology, 26, 667-692. DOI: https://doi.org/10.1146/annurev.soc.26.1.667.

SOBOTKA, T. (2002). Ten years of rapid fertility changes in the European post-communist countries. Working Paper Series 02-1. Groningen (Population and Research Centre, University of Groningen).

SOBOTKA, T. (2004). Postponement of childbearing and low fertility in Europe. Amsterdam (Dutch University Press).

SOBOTKA, T. (2011). Fertility in Central and Eastern Europe after 1989: Collapse and gradual recovery. Historical Social Research, 36, 246-298. DOI: https://doi.org/ 10.12759/hsr.36.2011.2.246-296.

SOBOTKA, T., SKIRBEKK, V., PHILIPOV, D. (2011). Economic recession and fertility in the developed world. Population and Development Review, 37, 267-306. DOI: https://doi.org/10.1111/j.1728-4457.2011.00411.x.

SOBOTKA, T., BEAUJOUAN, É., Van BAVEL, J. (2017). Introduction: education and fertility in low-fertility settings. Vienna Y earbook of Population Research, 15, 1-16.

ŠPROCHA, B., DŽAMBAZOVIČ, R. (2020). Kto s kým vstupuje do manželstva na Slovensku? K niektorým aspektom výberu manželského partnera v rokoch $1992-2018$. Sociológia 52, 374-402. DOI: https://doi.org/10.31577/sociologia.2020.52.4.16.

ŠPROCHA, B., POTANČOKOVÁ, M. (2010). Vzdelanie ako diferenčný faktor reprodukčného správania. Bratislava (INFOSTAT).

ŠPROCHA, B., TIŠLIAR, P. (2016). Transformácia plodnosti žien Slovenska v 20. a na začiatku 21. storočia. Bratislava (Muzeológia a kultúrne dedičstvo).

ŠPROCHA, B., TIŠLIAR, P. (2018). 100 rokov obyvatel'stva Slovenska: od vzniku Československa po súčasnost'. Bratislava (Muzeológia a kultúrne dedičstvo).

ŠPROCHA, B., TIŚLIAR, P. (2019). Najvyššie dosiahnuté vzdelanie a jeho vplyv na transformujúce sa reprodukčné správanie žien na Slovensku. Bratislava (PU SAV).

ŠPROCHA, B., ed., BLEHA, B., GARAJOVÁ, A., PILINSKÁ, V., MÉSZÁROS, J. VAŇO, B. (2019). Populačný vývoj v krajoch a okresoch Slovenska od začiatku 21. storocia. Bratislava (INFOSTAT).

ŠÚ SR (1992 - 1996 a 2015 - 2019) anonymizované primárne údaje Hlásenie o narodení Obyv 2-12. Bratislava (Štatistický úrad SR).

Van de KAA, D. J. (1987). Europe's second demographic transition. Population Bulletin, 42(1), 1-59.

Van de KAA, D. J. (1996). Anchored narratives: The story and findings of half a century of research into determinants of fertility. Population Studies, 50, 389-432. DOI: https:// doi.org/10.1080/0032472031000149546.

\section{Branislav Šp rocha, Vladimír B a č i k}

\section{FEMALE EDUCATION AND THE TIMING OF CHILDBIRTH IN SLOVAKIA IN A SPATIAL PERSPECTIVE}

Postponement of childbearing is one of the key aspects of the transformation of fertility rates in Slovakia. Extending the study period and raising the level of education play an important role in the process of postponing fertility. At the national level, this relationship is relatively well analyzed, but at a regional level, this aspect is overlooked. The aim of this paper is therefore to find an answer to the question: Are there differences of whether there are differences in Slovakia in selected aspects of fertility timing within individual levels of education? How the existing differences between levels of education have evolved over time and space? The analysis included data on the age of mothers at the birth of a child, the order of birth, place of residence and education of the mother. We analyzed selected indicators in 5-year intervals (1992-1996 and 2015-2019) at a district level. These reflected the beginning of the postponement process and the current last known state. From the input 
data, some indicators of fertility timing and age distribution were constructed and analyzed: mean age at birth, mean age at first birth, proportion of fertility of women under 25, proportion of fertility of women aged $30+$ to total fertility and interquartile range.

The obtained results confirmed the existence of a positive educational gradient in terms of fertility timing also at a district level and its persistence over time. At the same time, they also pointed out the considerably differentiated dynamics of the fertility postponement. This process was most dynamic among women with secondary education. The situation was relatively complicated for women with low education. Districts in Eastern Slovakia were characterized by small changes in timing, while women in the west experienced a relatively significant delay.

The result of these changes is a relatively significant East-West gradient in fertility timing among women with low education. This educational group is also characterized by the greatest age pluralization. The situation is quite the opposite in the most educated women. There are relatively small spatial differences in the timing of fertility and the overall persistent concentration of reproduction in a relatively short age interval. 
